Abstracta Iranicacta Iranica

Revue bibliographique pour le domaine irano-aryen

Volume 42-43 | 2021

Comptes rendus des publications de 2019-2020

\title{
Yutaka Yoshida. Three Manichaean Sogdian letters unearthed in Bäzäklik, Turfan
}

\section{Antje Wendtland}

\section{(2) OpenEdition}

1 Journals

\section{Electronic version}

URL: https://journals.openedition.org/abstractairanica/54064

DOI: 10.4000/abstractairanica.54064

ISSN: 1961-960X

Publisher:

CNRS (UMR 7528 Mondes iraniens et indiens), Éditions de l'IFRI

\section{Electronic reference}

Antje Wendtland, "Yutaka Yoshida. Three Manichaean Sogdian letters unearthed in Bäzäklik, Turfan", Abstracta Iranica [Online], Volume 42-43 | 2021, document 2, Online since 30 December 2021, connection on 12 December 2022. URL: http://journals.openedition.org/abstractairanica/54064 ; DOI: https://doi.org/10.4000/abstractairanica.54064

This text was automatically generated on 12 December 2022.

All rights reserved 


\title{
Yutaka Yoshida. Three Manichaean Sogdian letters unearthed in Bäzäklik, Turfan
}

\author{
Antje Wendtland
}

\section{REFERENCES}

Yutaka Yoshida. Three Manichaean Sogdian letters unearthed in Bäzäklik, Turfan. Tokyo: Rinsen Book Co., 2019, 278 p., 10 planches, 2 cartes.

1 The three Sogdian letters presented in this volume were discovered in excavations in Bäzäklik in 1980 and 1981 - together with five Uighur letters. The present edition is the revised English version of the first publication of all eight texts, with T. Moriyasu, in Chinese (Studies in the new Manichaean texts recovered from Turfan, Cultural Relics Publishing House, Beijing, 2000), and in Japanese ("Manichaean Sogdian and Uighur letters recently unearthed in Bäzäklik, Turfan", Studies in the Inner Asian Languages XV, 2000, p. 135-178).

2 Y. dates the letters to the beginning of the $11^{\text {th }}$ century. The first two letters (A and B) are addressed to the leader of the Eastern diocese, the možak Mār Aryāmān Puhr, and are of official nature. They give remarkable insight into the Eastern Manichaean community and its organization. They are written to bid greetings for the New Year celebrations and to excuse the non-attendance of the sender, the bishop Sharyār Zādag. Whereas the first letter is dedicated to wishes of auspiciousness for the ceremonies and the community, the second letter lists the religious services conducted by the sender and his community. Both letters contain extraordinarily long introduction formulas not using any punctuation ( 25 of 135 lines and 40 of 79 lines, respectively), praising the addressee with powerful eloquence in a very elaborate manner. Letter $\mathrm{C}$ is more private and shorter (29 lines), written by a monk to his elder. As letter A, it contains Turkish 
names and titles but also significantly more Uighur elements and loan translations than the other texts, which makes it hard to understand.

3 The letters show grammatical features, morphological elements, syntactical constructions and compounds that are quite unique. Also, differing from Sogdian syntax as known so far, there are no sentence-initial conjunctions, adjectives may follow the noun and definite articles are lacking completely. There is a frequent use of present participles and other non-finite constructions, a finite verb is often missing, and pre- and postpositions are used with meanings deviating from those in other Sogdian texts. Unusual spellings with short vowels written occur quite often are reminiscent of Uighur spellings of Sogdian loanwords. These characteristics suggest a potentially strong Uighur influence on the language of the writers. Y. commented on many of these "Turco-Sogdian features" in W. Sundermann, A. Hintze, F. de Blois (eds.). Exigisti Monumenta: Festschrift in Honour of Nicholas Sims-Williams. Wiesbaden: Harrassowitz, 2009, p. 571-585.

4 It would be interesting to find out if certain grammatical features, morphological elements and loan translations in letters A and B that are written in a very formal and hitherto unique style could also be found in more colloquial $11^{\text {th }}$ century Sogdian or are confined to a ceremonial style for festive occasions. It is of great value for Iranian, Uighur and Religious Studies that these Manichaean letters are now available in Professor Yoshida's excellent edition in English.

\section{AUTHORS}

\section{ANTJE WENDTLAND}

Allemagne 